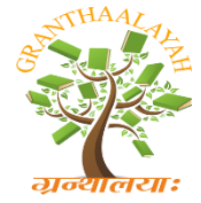

$$
\begin{gathered}
\text { INTERNATIONAL JOURNAL OF RESEARCH - } \\
\text { GRANTHAALAYAH } \\
\text { A knowledge Repository }
\end{gathered}
$$

Science

\title{
STUDY ON PRODUCTION POTENTIAL AND PRESERVATION METHODS OF HIDE AND SKIN IN THREE SELECTED DISTRICTS OF GAMBELLA REGION, SOUTH WEST ETHIOPIA
}

\author{
Getachew Bekele Fereja*1, Merhun Lamaro², Genet Berhe ${ }^{3}$, Aregay Berhe \\ $* 1,2,3,4$ Department of Animal Production and Health, College of Agriculture and Natural \\ Resource, Gambella University, PO Box 126, Gambella, Ethiopia
}

DOI: https://doi.org/10.29121/granthaalayah.v5.i2.2017.1715

\begin{abstract}
Ethiopia is believed to have the largest livestock population in Africa. An estimate indicates that the country is a home for about 54 million cattle, 25.5 million sheep and 24.06 million goats. Therefore, this study was conducted in three selected districts of Gambelia regional state with the objective to assess the production potentials and preservation methods of hide and skin. As a secondary product of the meat consumption, the supply of hides \& skins depends on the demand for meat, the rearing, management and slaughtering of animals, with little response to change in price and demand for the products. Hides and skins could be obtained from fish, birds and reptiles as well as wild and domesticated animals. The sample size of the study was estimated to be 384 (128 from Gambella zuria, 128 from Godare and 128 from Lare) using the formula stated in Thrust field. The quantitative data was organized, summarized and encoded on excel sheet and analyzed with the help of Statistical Analysis System (SAS) 9.2 version 2008.Qualitative data derived from direct observations and key informants was examined and presented in form of discussions. In the study areas, for all the three species, the mean annual slaughter at household level ranges between $0.07,1.66$ and 1.73 cattle, sheep and goat annually, respectively in the study area. Of the 384 respondents interviewed, (94.01\%) used the preservation methods of ground air dry and $6.25 \%$ use salt preservation for hide and skin preservation, respectively. Generally, production potential and preservation methods variations were observed among the Hide and skin producers, which suggest that there is an opportunity for improvement through awareness creation.
\end{abstract}

Keywords: Gambelia; Hide and Skin; Preservation.

Cite This Article: Getachew Bekele Fereja, Merhun Lamaro, Genet Berhe, and Aregay Berhe. (2017). "STUDY ON PRODUCTION POTENTIAL AND PRESERVATION METHODS OF HIDE AND SKIN IN THREE SELECTED DISTRICTS OF GAMBELLA REGION, SOUTH WEST ETHIOPIA.” International Journal of Research - Granthaalayah, 5(2), 142-150. https://doi.org/10.29121/granthaalayah.v5.i2.2017.1715. 


\section{Introduction}

Ethiopia is believed to have the largest livestock population in Africa (CSA, 2013). An estimate indicates that the country is a home for about 54 million cattle, 25.5 million sheep and 24.06 million goats (CSA, 2013). From 1995/96 to 2012/13 the cattle and shoat population grew from 54.5 million to over 103.5 million with average annual increment of 3.4 million (CSA, 2013). The livestock population of the country will continue to grow. In 2024/25 the cattle, sheep and goat population in sedentary areas of Ethiopia are estimated to reach 75, 42.8 and 39.6 million heads, respectively (Leta \& Melese, 2014).

The GDP of livestock related activities valued at birr 59 billion (Metaferia et al, 2011). It is eminent that livestock products and by-products in the form of meat, milk, honey, eggs, cheese, and butter supply provide the needed animal protein that contributes to the improvement of the nutritional status of the people (CSA, 2011). As a secondary product of the meat consumption, the supply of hides \& skins depends on the demand for meat, the rearing, management and slaughtering of animals, with little response to change in price and demand for the products (Arugna, 1995). The availability of hides and skins through slaughtering or death of livestock is of importance to the leather industry (FAO, 1998).

Hides and skins could be obtained from fish, birds and reptiles as well as wild and domesticated animals. The most important sources are cattle, sheep and goats. Based on annual off take rates of $7 \%$ for cattle, $33 \%$ for sheep and $35 \%$ for goats, the potential production is estimated at 2.38 million cattle hides, 10.07 million sheep skins and 7.38 million goat skins in 1998/99. This raw material of the leather industry is mainly derived from local areas of the country where basic amenities for slaughtering and subsequent marketing are either not inexistence or lacking (Ahmed, 2000). Gambella is one of the potential region which consists of the population number of 253,389 cattle, 39,564 sheep and 83, 897 goats (CSA, 2013). Despite high livestock population and existing favorable environmental conditions, the current livestock output of the region is little. Hence, the objective of this study was to assess the production potentials and preservation methods of hide and skin in three selected districts of Gambella regional state.

\section{Materials and Methods}

\subsection{Description of the Study Area}

Gambella People's National Regional State (GPNRS) is located South West part of Ethiopia between the geographical coordinates $6^{0} 28^{\prime} 38^{\prime \prime}$ to $8^{0} 34^{\prime}$ North Latitude and $33^{\circ}$ to $35^{0} 11^{\prime} 11^{\prime \prime}$ East Longitude, which covers an area of about $34,063 \mathrm{~km}^{2}$ which is about $3 \%$ of the nation. The Region is bounded to the North, North East and East by Oromia National Regional State, to the South and South East by the Southern Nations and Nationalities People's Regional State and to the Southwest, West and Northwest by the Republic of South Sudan. The topography of the Region is divided in to two broad classes, i.e. the Lower Piedmonts between 500 to 1900 m.a.s.l. and the Flood Plains of below 500m contours (CSA, 2007). The mean annual temperature of the Region varies from $17.3^{\circ} \mathrm{C}$ to $28.3^{\circ} \mathrm{C}$ and annual monthly temperature varies throughout the year from $27^{\circ} \mathrm{C}$ to $35^{\circ} \mathrm{C}$. The absolute maximum temperature occurs in mid-March and is about $45^{\circ} \mathrm{C}$. 
The annual rainfall of the Region in the lower altitudes varies from 900-1500mm. At higher altitudes, it ranges from 1,900-2,100mm. The annual vapor-transpiration in the region reaches about 1,612mm and the maximum value occurs in March and is about 212mm (CSA, 2013). Livestock population of the region is about 253,389 cattle, 39,564 sheep and 83, 897 goats (CSA, 2013).

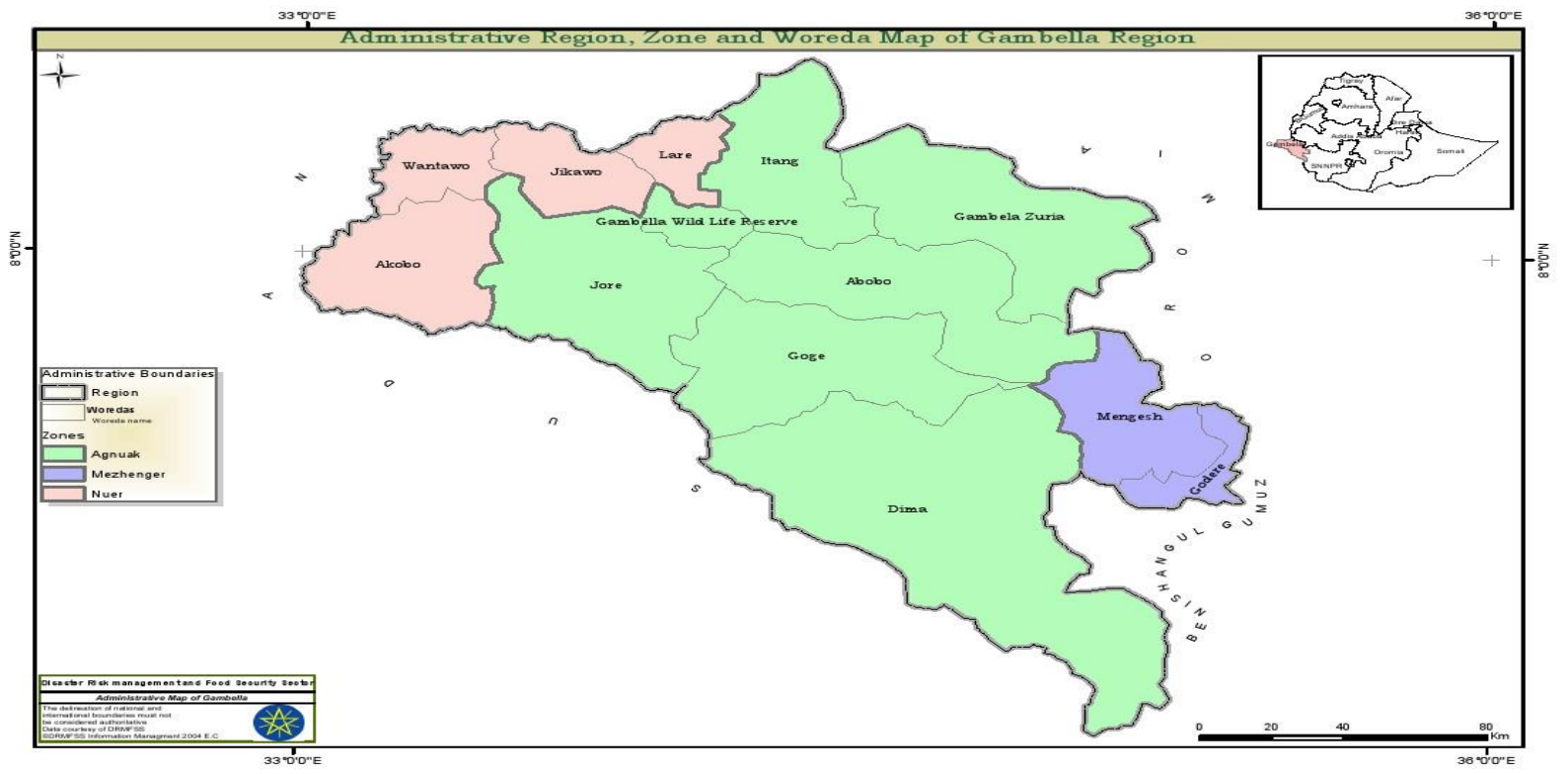

Figure 1: Map of the study area

\subsection{Study Design and Population}

The study was involved field visits and observation, focus group discussions and key informant interviews. The study population was the producers of cattle hide and skin of sheep and goats.

\subsection{Sampling Procedures and Determination of Sample Size}

The three districts of the region called Gambella Zuria, Godare and Lare districts were purposively selected based on the ecology and potential of hide and skin production in the region. These districts were chosen as they are the major livestock producing and meat product user areas of the districts and also slaughtering slabs and traders are found in these towns and also the rural PA were selected randomly based on the accessibility and security. The sample size of the study was estimated to be 384 (128 from Gambella zuria, 128 from Godare and 128 from Lare) using the formula stated in Thrust field (2007).

$\mathrm{N}=\frac{\mathrm{Z}^{2} \propto 2 \mathrm{P}(1-\mathrm{P})}{\mathrm{d}^{2}}=1.96^{2} \frac{* 0.5(1-0.5)}{0.05^{2}}=384$

Where $\mathrm{P}=$ Proportion of people who knows about hide and skin preservation; since the preservation of hide and skin in the study area is not known, the researchers took 0.5 as a standard. 
$\mathrm{Z}=1.96$ at $95 \%$ confidence interval

$\mathrm{d}=$ expected margin of errors, i.e. 0.05

$\mathrm{N}=$ required sample size

\subsection{Method of Data Collection}

Different data collecting techniques were applied to collect primary and secondary data which include individual interviews with the help of semi structured questionnaires. The other method which was applied in data collection was direct observation. The researchers also visited the slaughter houses, and stores where hides and skins were stored. In addition, informal discussions were held with a group of households in each of the town and with hide and skin traders. The actual data collection took six months which extended from March 2016 to August 2016.

\subsection{Methods of Data Analysis}

The quantitative data was organized, summarized and encoded on excel sheet and analyzed with the help of Statistical Analysis System (SAS) 9.2 version 2008.Qualitative data derived from direct observations and key informants was examined and presented in form of discussions. Descriptive statistics was used to run to give frequencies. Tables and bar charts were used to present different variables. Chi-square was used to evaluate the statistical significance of the difference between towns and stakeholders where $\mathrm{P}$ value $<0.05$ was considered significant.

The effects of class were expressed as Least Square Means (LSM) \pm SE and means was separated using Least Significance Difference (LSD).

The statistical model used for the study was:

Yijk $=m+k+e j k$

Where: $Y j k=$ the observed (weight of hide and skin in the $\mathrm{j}^{\text {th }}$ and $\mathrm{k}^{\text {th }}$ district

$\mathrm{m}=$ overall mean

$\mathrm{k}=$ the effect of districts $(\mathrm{k}=1,2,3)$

$\mathrm{ejk}=$ random residual error

\section{Results and Discussion}

\subsection{Socio-Economic Status And Respondent's Profile}

General characteristics of the respondents studied were presented in Table 1. From the total interviewed hide and skin owners in the study area, about $(76.04 \%)$ and $(23.96 \%)$ were male and female, respectively. The average age of respondents was 44.75 years in godare, 41.85 years in Lare and 42.78 years in Gambella Zuria. Concerning educational background, the majority $(48.44 \%)$ of the respondents were illiterate. This considerably high number of illiterates might influence negatively the perception of hide and skin production and preservation technology transfer. The number of illiterates observed in this study was in line with the reported $50 \%$ for Adami Tulu -JidoKombolcha and Bora Woreda's of Oromia regional state (Aleminesh, 2015). However, this result is lower than $97.3 \% \%$ and $72.34 \%$ for Hetosa and Dodota Woreda's of Oromia (Abaineshe, 2014). From the literate members, 19.53\%, 18.75\%, 9.89\%, 2.60\% and 
$0.78 \%$ had gone through reading and writing, grade 1-4 education, grade 5-8, grade 9-12 and certificate, respectively.

The overall mean family size of the study area was 6.95 which are higher than the national average of 4.6 persons (CSA, 2011) and 5.4 persons per household for Northwest Amhara (Halima, 2007). However, this is comparable to the findings of Fisseha et al., (2010b) who reported 6.2 and 6.9 persons per household for Bure and Dale Woreda, respectively.

Table 1: Socio-economic characteristics of the respondents in the study area

\begin{tabular}{|c|c|c|c|c|}
\hline \multirow{2}{*}{ Parameters } & \multicolumn{3}{|c|}{ Districts } & \multirow{2}{*}{ Over all } \\
\hline & Godare & Lare & Gambella zuria & \\
\hline Age of the respondents & $44.75 \pm 0.02^{\mathrm{a}}$ & $41.85 \pm 0.21^{\mathrm{b}}$ & $42.78 \pm 0.06^{\mathrm{ab}}$ & $43.13 \pm 0.09$ \\
\hline Family size/HH & $4.98 \pm 0.27^{\mathrm{c}}$ & $9.21 \pm 0.23^{\mathrm{a}}$ & $6.67 \pm 0.25^{b}$ & $6.95 \pm 0.25$ \\
\hline Sex & \multicolumn{3}{|c|}{ Frequency, (\%) } & \\
\hline Male & $107(83.59)$ & $86(67.19)$ & $99(77.34)$ & $292(76.04)$ \\
\hline Female & $21 \quad(16.41)$ & $42(32.81)$ & $29(22.66)$ & $92(23.96)$ \\
\hline \multicolumn{5}{|l|}{$\begin{array}{l}\text { Educational } \\
\text { background }\end{array}$} \\
\hline Illiterate & $61(47.66)$ & $66(51.56)$ & $59(46.09)$ & $186(48.44)$ \\
\hline Read and write & $21(16.41)$ & $25(19.53)$ & $29(22.66)$ & $75(19.53)$ \\
\hline Grade 1-4 & $26(20.31)$ & $24(18.75)$ & $22(17.19)$ & $72(18.75)$ \\
\hline Grade 5-8 & $16(12.50)$ & $8(6.25)$ & $14(10.94)$ & $38(9.89)$ \\
\hline Grade $9-12$ & $4(3.13)$ & $3(2.34)$ & $3(2.34)$ & $10(2.60)$ \\
\hline Certificate & $0(00)$ & $2(1.56)$ & $1(0.78)$ & $3(0.78)$ \\
\hline Livestock holding/HH & \multicolumn{3}{|l|}{ Mean \pm SE } & \\
\hline Cattle & $6.32 \pm 0.55^{b}$ & $33.22 \pm 0.85^{\mathrm{a}}$ & $6.35 \pm 0.65^{b}$ & $15.29 \pm 0.68$ \\
\hline Goat & $5.39 \pm 0.25^{\mathrm{b}}$ & $6.94 \pm 0.45^{\mathrm{a}}$ & $6.47 \pm 0.35^{\mathrm{ab}}$ & $6.27 \pm 0.35$ \\
\hline Sheep & $4.21 \pm 0.29^{c}$ & $7.67 \pm 0.49^{\mathrm{a}}$ & $6.11 \pm 0.39^{b}$ & $5.99 \pm 0.39$ \\
\hline Poultry & $4.68 \pm 0.09^{c}$ & $5.08 \pm 0.07^{\mathrm{ab}}$ & $6.22 \pm 0.12^{\mathrm{a}}$ & $5.33 \pm 0.09$ \\
\hline Donkey & $0.05 \pm 0.03^{\mathrm{a}}$ & $0.02 \pm 0.01^{\mathrm{b}}$ & $0.03 \pm 0.02^{\mathrm{b}}$ & $0.03 \pm 0.02$ \\
\hline Horse & - & - & - & - \\
\hline Mule & - & - & - & - \\
\hline
\end{tabular}

$\mathrm{a}, \mathrm{b}, \mathrm{c}$ means with different superscript letters across a row are significantly different at $\mathrm{p}<0.05$; $\mathrm{ns}=$ non-significance, $\mathrm{HH}=$ interviewed households.

The results from table 1 also indicate that the farmers in the study area rear various types of livestock species including cattle, sheep, goat and chickens. The results obtained are significantly higher than the results of Abainesh (2014) about cattle 7.35 and Mekonnen (2007) with regard to cattle 3.12. This difference may be attributed to the variations in the availability of feed resources and priority of preference of the farmers to rear according to the relative importance of the animals. The group discussion held in the current study revealed that cattle are the main source of draft power, and sale of animals and animal products were an important source of household cash income. 


\subsection{Purpose of Hide and Skin Production in the Study Area}

Hide and skin production is commonly practiced as additional activity and none of the respondents specialized in this activity. However, importance and uses of hide and skin production in the context of smallholder farmers were multi-directional (Table 2). From the three districts had shown that hide and skin are primarily used for income generation and secondly used for bedding purpose in all districts. This is highly significant than (Alemnesh 2015) who reported that the use of hide and skin (73.5\%) was the first function of cash income in Adami Tulu -JidoKombolcha and Bora.

Table 2: Purpose of hide and skin for farmers

\begin{tabular}{|c|c|c|c|}
\hline \multirow{2}{*}{ Use of hide and skin (\%) } & \multicolumn{3}{|c|}{ District } \\
\cline { 2 - 4 } & Godare & Lare & Gambella Zuria \\
\hline Cash income & $128(100.00)$ & $128(100.00)$ & $128(100.00)$ \\
\hline Bedding & $35(27.34)$ & $25(19.53)$ & $16(12.5)$ \\
\hline For container & $12(9.38)$ & $0(0.00)$ & $0(0.00)$ \\
\hline
\end{tabular}

Note: the single house hold used hide and skin for more than one purpose.

Household respondents ascertained that majority of them use hide and skins for cash income whereas less number of them keeps the raw materials for making household bedding. However, the majority of the farmers do not use hide and skin for container.

According to the respondents, cattle were kept for multipurpose functions. These include milk, hide and skin production for cash income and also as sign of wealth. Most the households in both Woreda keep ruminant for milk production, while some of them kept for cash income, only few of respondents keep livestock as sign of wealth. There is no significant difference $(\mathrm{P}>0.05)$ in the purpose of keeping ruminant livestock between the three districts. Moreover, the importance of hide and skin is appreciated almost similarly by respondents from all study areas. (100\%) and $(19.79 \%)$ of both cattle and sheep owners rank hide as more important than sheep skin in all the study area respectively (Table 2 ).

\subsection{The Production Potential of Hide and Skin in the Study Area}

All interviewed household respondents practiced annually slaughtering species of livestock such as cattle, sheep and goats which are the widely prevalent species in all study areas. In the study areas, for all the three species, the mean annual slaughter at household level ranges between 0.07,1.66 and 1.73 cattle, sheep and goat annually, respectively in the study area (Table3).

Table 3: Mean annual slaughtered livestock at house hold level

\begin{tabular}{|l|c|c|l|l|}
\hline \multicolumn{1}{|c|}{$\begin{array}{c}\text { Type of animal slaughtered } \\
\text { Mean } \pm \text { SE }\end{array}$} & \multicolumn{3}{c|}{ District } & \multirow{2}{*}{$\begin{array}{c}\text { Over } \\
\text { all }\end{array}$} \\
\cline { 2 - 4 } & Godare & Lare & Gambella Zuria & $0.07 \pm 0.02$ \\
\hline Cattle slaughtered & $0.06 \pm 0.01$ & $0.09 \pm 0.03$ & $0.08 \pm 0.02$ & 02 \\
\hline Sheep slaughtered & $1.98 \pm 0.09$ & $1.46 \pm 0.05$ & $1.54 \pm 0.07$ & $1.66 \pm 0.07$ \\
\hline Goat slaughtered & $2.09 \pm 0.16$ & $1.67 \pm 0.12$ & $1.42 \pm 0.11$ & $1.73 \pm 0.17$ \\
\hline
\end{tabular}


The overall mean of animal slaughtered by respondents of cattle, sheep and goat was 0.07, 1.66 and 1.73 respectively in the study areas. The result reported in this research work is lower than 2.55, 2.75 and 2.94 of cattle, sheep and goat per household in Adami Tulu -JidoKombolcha and Bora respectively as reported by Alemnesh (2015). This difference may be attributed to the variations in the availability of priority of preference by farmers to rear according to the relative importance of the animals.

\subsection{Preservation Methods of Hide and Skin in the Study Area}

Of the 384 respondents interviewed, (94.01\%) used the preservation methods of ground air dry and $6.25 \%$ use salt preservation for hide and skin preservation, respectively. The preservation methods of hide and skin for almost of respondents were traditional use. All of the interviewed respondents (100\%) do not use frame drying method (Table 4). One of the reason was the modern system of frame drying need high awareness creation to hide and skin producers at their residential area. On the contrary, none $(0.00 \%)$ of them consider frame drying preservation method of the hide and skin because their main purpose is meat and the income they earn by selling hide and skin is very little.

Table 4: Preservation methods of hide and skin used in the study area

\begin{tabular}{|l|c|c|c|c|}
\hline \multirow{2}{*}{ Preservation methods (\%) } & \multicolumn{3}{|c|}{ District } & \multirow{2}{*}{$\begin{array}{c}\text { Over all } \\
\text { mean }\end{array}$} \\
\cline { 2 - 4 } & Godare & Lare & Gambella Zuria & \\
\hline Ground air dry & $119(92.97)$ & $125(97.66)$ & $117(91.41)$ & $94.01 \%$ \\
\hline Salt & $7(5.47)$ & $5(3.91)$ & $12(9.38)$ & $6.25 \%$ \\
\hline Frame drying & $0(0.00)$ & $0(0.00)$ & $(0.00)$ & $0.00 \%$ \\
\hline
\end{tabular}

The distribution of hide and skin preservation methods in the study areas by respondents in all methods type is not on the same stage which was presented in table 5. The findings revealed that in all of the study area of hide and skins preservation methods higher variation was assessed. On the other hand, elongation capacity was within the standard range interviewer understanding for preservation of hide and skins to keep its quality.

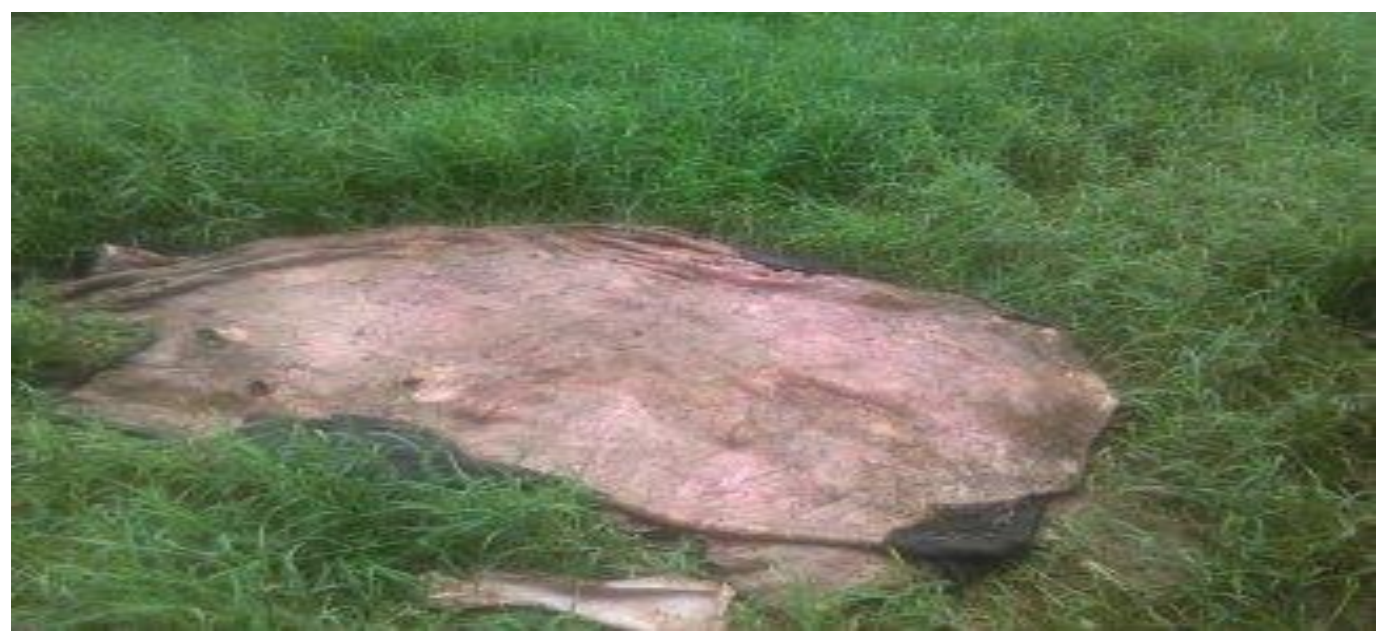

Figure 2: Ground air drying method in Lare Woreda 


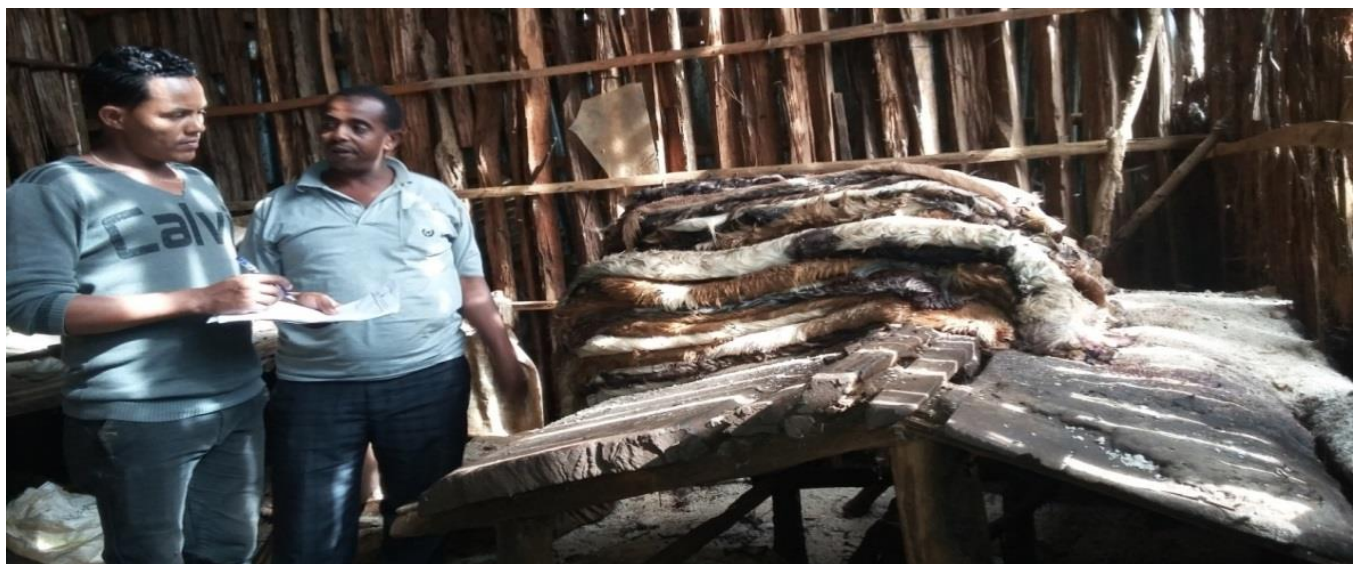

Figure 3: Preservation method and storage of sheep skin in Godare woreda skin storage place

\section{Conclusion}

Livestock plays vital roles in generating income to farmers, creating job opportunities, ensuring food security, providing different services, contributing to asset, social, cultural and environmental values, and sustain livelihoods.

As a secondary product of the meat consumption, the supply of hides \& skins depends on the demand for meat, the rearing, management and slaughtering of animals, with little response to change in price and demand for the products. The availability of hide and skins through slaughtering or death of livestock is of particular importance to the leather industry. Hide and skins could be obtained from fish, birds and reptiles as well as wild and domesticated animals. The most important sources are cattle, sheep and goats.

The present study was therefore conducted in three selected districts of Gambella region, South West Ethiopia to assess the production potentials and preservation methods of hide and skin. The three districts of the region called Gambella zuria, Godare and Lare were purposively selected based on the ecology and potential of hide and skin production in the region. These districts were chosen as they are the major livestock producing and meat product user areas of the region and also slaughtering slabs and traders are found in these towns and also the rural PA were selected randomly based on the accessibility and security.

The sample size was estimated to be 384 (128 from Gambella zuria, 128 from Godare and 128 from Lare) districts using the formula stated in Thrust field (2007), which was conducted using a structured questionnaire on hide and skin production potential and other related issues.

The data was subjected to descriptive statistics, frequency procedure and univariate analysis of SAS version 9.2 (2008). Hide and skin production is commonly practiced as additional activity and none of the respondents specialized in this activity. However, importance and uses of hide and skin production in the context of smallholder farmers were multi-directional. The results of rankings from Godare, Lare and Gambella zuria districts had shown that hide and skin as source of cash income generation was the first and bedding in all districts. 
In the study areas, for all the three species, the mean annual slaughter at house hold level ranges between $0.07,1.66$ and 1.73 cattle, sheep and goat, respectively. The mean average result indicates that flay cut defect $(65.89 \%)$ was the dominant defects in goat, sheep and cattle. Of the 384 respondents interviewed, $(94.01 \%)$ used the preservation methods of ground air dry and $6.25 \%$ use salt preservation methods for hide and skin preservation respectively. Despite the presence of village level collectors, no extension agent working on selling of hides and skin quality management as a focus area exists.

\section{References}

[1] Abaineshe Jarso, 2014. assessment of pre-slaughter hide and skin management in and around assela and sagure town, east arsi oromia regional state Ethiopia.

[2] Alemnesh Belete, 2015.assesment of quality and marketing of hide and skin in adamitulu jidokombolcha and bora woreda in east shewa zone of oromia regional state, Ethiopia.

[3] Arugna, R., 1995. Notes on the importance of hides, skins and leather products to the African.

[4] CSA (2013) Agricultural Sample Survey, 2012/13 (2005 E.C.), Volume II: Report on Livestock and livestock characteristics (Private peasant holdings). Statistical Bulletin 570. Central Statistical Agency (CSA), Federal Democratic Republic of Ethiopia, Addis Ababa.

[5] CSA (2011) Agricultural Sample Survey, 2010/11 (2003 E.C.), Volume II: Report on Livestock and livestock characteristics (Private peasant holdings). Statistical Bulletin 505. Central Statistical Agency (CSA), Federal Democratic Republic of Ethiopia, Addis Ababa.

[6] FAO, 1998. Control of Sheep and goat Skin Diseases for Improved Hide and skins (phase II), Ian, B. C. and Bayou, K. (eds.), Proceedings on hide and skin Improvement, pp: 13-14 Feb. 1998, FAO, Addis Ababa.

[7] Fisseha Moges, Azage Tegegne and Tadelle Dessi, 2010b. Indigenous chicken production and marketing systems in Ethiopia: Characteristics and opportunities for market-oriented development.

[8] Halima Hassen, 2007. Ph enotypic and genetic characterization of indigenous chicken populations in North-West Ethiopia. Ph.D Thesis. Submitted to the faculty of natural and agricultural sciences department of animal, wildlife and grassland Sciences. University of the Free State, Bloemfontein, South Africa. Pp186

[9] Leta S. and Moselle F. (2014): Spatial analysis of cattle and shoat population in Ethiopia: growth trend, distribution and market access. LMA, 1999/2000, Field survey reports of regional states. (Amharic version).

[10] Metaferia F, Cherenet T, Gelan A, Abnet F, Tesfay A, Ali JA, Gulilat W (2011) AReview to Improve Estimation of Livestock Contribution to the National GDP.Ministry of Finance and Economic Development and Ministry of Agriculture.Addia Ababa, Ethiopia.

[11] Mekonen G/gziabher, (2007). Characterization of the small holder poultry production and marketing system of Dale, Wonsho and Loka Abaya woredas of SNNPRS, Ethiopia. M.Sc Thesis. HawasUniversity, Ethiopia, Pp. 95

[12] SAS (Statistical Analysis System), 2008. SAS Institute Inc., Cary, NC, USA.V.9.2

*Corresponding author.

E-mail address: gechobek@gmail.com 